\title{
WOLONTARIAT W POLSCE PRZYKŁAD PROJEKTU POLSKA CYFROWA RÓWNYCH SZANS
}

\section{WPROWADZENIE}

Poniższy artykuł jest przedstawieniem case study - opisu konkretnej grupy wolontariuszy: Latarników Polski Cyfrowej. Celem artykułu jest deskrypcja zjawiska wolontariatu w projekcie Polska Cyfrowa Równych Szans (PCRS), umieszczenie go w szerszym kontekście wolontariatu w Polsce oraz próba postawienia diagnozy dotyczącej sytuacji i przyszłości wolontariatu w naszym kraju. Badanie, którego wyniki przedstawiam poniżej, miało charakter - można by powiedzieć - marketingowy, a jego wynikiem jest s e g m en ta cj a ryn$\mathrm{ku}$ Latarników, czyli wyodrębnienie typologii wolontariuszy projektu PCRS. Badanie prowadzone było w taki sposób, aby jego wyniki miały zastosowanie praktyczne dla koordynatorów projektu, a służyć miało lepszemu poznaniu osób, które zaangażowały się w działania na rzeczy przeciwdziałania wykluczeniu cyfrowemu.

\section{WOLONTARIAT W POLSCE - UWAGI WSTĘPNE}

Centrum Wolontariatu ${ }^{1}$ definiuje wolontariat jako dobrowolną i bezpłatna pracę na rzecz innych osób (z pominięciem najbliższego kręgu rodziny i znajomych). Jak wynika z badań przeprowadzonych przez Stowarzyszenie Klon/ Jawor, wolontariat rozumiany jest przede wszystkim jako nieodpłatna pomoc świadczona na rzecz innych ludzi będących w potrzebie ${ }^{2}$. W Polsce zasady działania wolontariatu reguluje ustawa o działalności pożytku publicznego i wolontariacie ${ }^{3}$. Pierwszy zapis regulujący działania wolontariuszy w Polsce pojawił się dopiero w 2000 r. w rozporządzeniu Ministra Pracy i Polityki Społecznej ${ }^{4}$.

\footnotetext{
${ }^{1}$ Zob. www.wolontariat.org.pl.

${ }^{2}$ P. Teisseyre, Jak rozumiemy wolontariat, Stowarzyszenie Klon/Jawor, 2014, http://fakty. ngo./plwiadomosc/961811.html [dostęp: 10.03.2016].

${ }^{3}$ Por. Eurobarometr.

${ }^{4}$ M. Nowosielski, Odradzanie się społeczeństwa obywatelskiego. Rozwój polskiego trzeciego sektora w latach 1989-2008, Instytut Zachodni, Poznań 2008.
} 
Polska pod względem rozwoju trzeciego sektora i pracy wolontariackiej wykazuje mierne rezultaty $\mathrm{w}$ porównaniu z krajami skandynawskimi oraz państwami Europy Zachodniej ${ }^{5}$. Winny tego stanu rzeczy jest w dużej mierze okres PRL, podczas którego zahamowany został rozwój inicjatyw obywatelskich, wypaczone zostało także rozumienie pojęcia „praca społeczna”. Przez lata komunistycznych rządów w Polsce społeczeństwo obywatelskie i organizacje pozarządowe nie mogły się swobodnie rozwijać. Władze zamiast postrzegać organizacje pozarządowe jako potencjalnego partnera, mogącego pomóc w realizacji niektórych zadań, patrzyła na nie niechętnie, klasa polityczna zaś miała do trzeciego sektora stosunek często lekceważący ${ }^{6}$.

Mimo niesprzyjających warunków działacze nie zniechęcali się i tuż po 1989 r. zaczęły powstawać liczne organizacje pozarządowe budujące nowe społeczeństwo obywatelskie. Społeczny kontekst rozwoju trzeciego sektora nie był sprzyjajacy. Największą przeszkodą okazały się niewielki kapitał społeczny polskiego społeczeństwa oraz niski poziom zaufania społecznego (szczególnie do administracji publicznej). Niski kapitał społeczny uniemożliwiał skuteczna współpracę i wywierał bardzo silny wpływ na gotowość do społecznego angażowania się, wolontariatu czy też pomocy potrzebującym. To właśnie kapitał społeczny warunkuje umiejętność kooperacji zarówno w obrębie organizacji, całego sektora, jak i z innymi partnerami ${ }^{7}$.

Brak kapitału społecznego oraz zaufania społecznego jest wynikiem historycznych losów Polski, w tym: powolnej modernizacji, wojen, które wyniszczyły elitę kraju, masowych przesiedleń mieszkańców, co burzyło ciąłość kontaktów, brak demokratycznego państwa w czasach PRL. Jeszcze w wiele lat po transformacji widoczny był "społeczny bezruch” w Polsce, który w radzeniu sobie przejawiał się przewagą strategii indywidualistycznych nad kolektywnymi i kooperacyjnymi. Zaufaniem darzona była tylko najbliższa rodzina i wszelkie aktywności podejmowane były właśnie w jej ramach.

Wolontariat, czyli ,[...] nieodpłatna praca społeczna ma w Polsce długa tradycję. Zarówno w Polsce przedrozbiorowej, jak i w II RP wśród niektórych warstw społecznych częsta była postawa społecznikowska, polegająca na podejmowaniu działań na rzecz innych, bardziej potrzebujących ludzi. Jednak okres PRL doprowadził do dewaluacji pojęcia pracy społecznej - liczne obowiązkowe czyny społeczne wpisujące się $\mathrm{w}$ ideologię komunistyczną i mające być $\mathrm{w}$ istocie wyrazami poparcia dla systemu sprawiły, że duża część Polaków zaczęła traktować tego typu działania z dużą podejrzliwością. Jest to jedna z podstawowych przyczyn, dla których budowa nowoczesnego wolontariatu w Polsce po 1989 r. trwa tak długo"s.

W 2013 r. 18\% Polaków i Polek świadczyło nieodpłatna pomoc na rzecz organizacji pozarządowych, $27 \%$ wpierało osoby spoza swojej najbliższej rodziny, prawie $9 \%$ pracowało na rzecz związku wyznaniowego lub parafii. W sumie $34 \%$ Polaków zaangażowało się w jakąkolwiek pracę społeczną?

\footnotetext{
5 M. Nowosielski, op. cit.

6 Ibidem.

7 Ibidem, s. 9.

8 Ibidem, s. 37.

9 Źródło: civicpedia.ngo.pl [dostęp: 10.03.2016].
} 


\section{WOLONTARIAT W PROJEKCIE PCRS}

Projekt Polska Cyfrowa Równych Szans powstał jako odpowiedź na zjawisko wykluczenia cyfrowego Polaków powyżej 50 roku życia. Główną siłą napędową projektu są Latarnicy - wolontariusze, którzy mają działać w ramach swoich lokalnych społeczności i pomagać osobom w wieku 50+ zapoznawać się z technologiami cyfrowymi. Projekt jest oddolna inicjatywa, pomysłem Stowarzyszenia „Miasta w Internecie”, który przy wsparciu Ministerstwa Administracji i Cyfryzacji oraz Funduszy Europejskich rozpoczą się w listopadzie 2011 r. ${ }^{10}$ Głównym celem projektu jest przeciwdziałanie wykluczeniu cyfrowemu osób 50+, ale cele poboczne to m.in.: cementowanie społeczności lokalnej, neutralizacja różnic międzypokoleniowych, aktywizacja osób mieszkających na wsi i w małych miejscowościach.

Latarnicy to lokalni liderzy, entuzjaści edukacji cyfrowej, osoby cieszące się zaufaniem swojej lokalnej społeczności, posiadające z reguły znaczny kapitał społeczny. Ich głównym zadaniem jest pomoc osobom 50+ w nabyciu takich umiejętności korzystania z komputera i Internetu, które poprawiaja jakość życia i pracy seniorów. Latarnicy mają więc prowadzić zajęcia dla osób starszych, w publicznych punktach dostępu do Internetu (takich jak szkoły, biblioteki, domy kultury).

W projekcie Polska Cyfrowa Równych Szans bierze udział ponad 2600 wolontariuszy. Ta liczba, to wolontariusze, którzy przeszli szkolenie i posiadaja certyfikat Latarnika Polski Cyfrowej. Dostęp do szkoleń był otwarty (nie było procesu rekrutacji na szkolenia), każdy, kto czuł się na siłach, aby uczyć innych, i posiadał podstawowe kompetencje cyfrowe, mógł wziąc udział w projekcie. Znajomość obsługi komputera na poziomie podstawowym była wystarczająca, gdyż zadaniem Latarnika miało być wprowadzenie osób 50+ w świat cyfrowy, a nie prowadzenie zaawansowanych szkoleń informatycznych. Latarnicy w trakcie szkoleń do nich kierowanych przygotowywani byli do pracy z seniorami i prowadzenia zajęć, które będą odpowiedzią na potrzeby seniorów, a także pomogą im przełamać początkowy strach przed nowymi technologiami. Na szkoleniach Latarnicy dowiadywali się także, jak skutecznie zachęcać seniorów do udziału w prowadzonych zajęciach oraz gdzie zgłosić się po pomoc w szukaniu miejsc wyposażonych w potrzebny do pracy sprzęt komputerowy. Latarnicy mają dostęp online do materiałów edukacyjnych, które mogą być im przydatne do przygotowywania zajęć dla osób 50+, a także do forum internetowego, na którym moga komunikować się z innymi Latarnikami i koordynatorami projektu. Stowarzyszenie „Miasta w Internecie” systematycznie organizuje też regionalne spotkania Latarników, a także Ogólnopolskie Zjazdy Latarników (pierwszy odbył się 2012 r. w Tarnowie, drugi - w 2013 w Olsztynie, trzeci - w 2014 w Łodzi, a czwarty - w 2015 w Lublinie).

Zadaniem Latarnika na początku działalności jest zorganizowanie miejsca na prowadzenie zajęć, a także pozyskanie ewentualnych partnerów do współpracy (spośród władz lokalnych), następnie zainteresowanie swoją dzia-

10 Źródło: https://latarnicy.pl/o-idei/ [dostęp: 10.03.2016]. 
łalnością seniorów i prowadzenie zajęć. Pod koniec 2012 r. rozstrzygnięty został konkurs grantowy na realizację Lokalnych Projektów Edukacji Cyfrowej, w rezultacie którego sfinansowanych zostało 200 projektów przygotowanych przez Latarników. Do połowy września 2013 r. Latarnicy spędzili ponad 23 tys. godzin na spotkaniach $\mathrm{z}$ seniorami, a przeszkolili ponad 85,5 tys. osób wykluczonych cyfrowo.

\section{OPIS BADANIA}

Przeprowadzone badanie było badaniem ilościowym, prowadzonym metodą ankiety internetowej. Stanowi wstęp do dalszych, pogłębionych badań jakościowych. Wiadomość z prośbą o wypełnienie ankiety została wysłana pocztą elektroniczna do każdego Latarnika zarejestrowanego w serwisie (ok. 2600 osób). Informacja o prowadzonym badaniu została także umieszczona na Facebooku - na profilu projektu Polska Cyfrowa Równych Szans. Wybór nowych technologii cyfrowych do komunikowania się z Latarnikami oraz ankiety internetowej do badania owej grupy jest uzasadniony z dwóch powodów: po pierwsze, Latarnicy to bardzo liczna grupa osób działająca w dużym rozproszeniu przestrzennym (cała Polska), co utrudniałoby dotarcie do nich osobiście; po drugie, Latarnicy jako „nauczyciele” cyfrowych technologii sa zaznajomieni z obsługa komputera i regularnie korzystaja z Internetu. Ankieta była dostępna w serwisie przez miesiąc (od 5 sierpnia do 4 września 2013 r.), wypełniły ja 264 osoby. Obecnie nie jest prowadzona żadna „centralna ewidencja Latarników", a dane, które otrzymało SMWI od osób biorących udział w szkoleniach, nie sa miarodajne, gdyż ponad połowa z osób przeszkolonych nie podjęła się próby zorganizowania zajęć dla seniorów. Dlatego też badanie, którego wyniki przedstawiam poniżej, jest jednym z nielicznych źródeł wiedzy na temat tego, kim są Latarnicy Polski Cyfrowej.

\section{Profil wolontariusza}

Jak wynika z raportu CBOS-u Młody, bogaty, wykształcony, religijny - mit polskiego wolontariusza ${ }^{11}$, ogólnie panujący wizerunek wolontariusza jako osoby młodej, wykształconej i bogatej nie do końca odpowiada rzeczywistemu stanowi rzeczy. W kolejnym raporcie CBOS-u Potencjat spotecznikowski $i$ zaangażowanie Polaków $w$ wolontariat ${ }^{12}$ możemy znaleźć dane pokazujące, że: „ponadprzeciętną aktywność społeczną deklarują osoby w wieku 35-54 lata, żyjące w mniejszych miejscowościach - przede wszystkim na wsiach, legitymujące się wykształceniem wyższym i zasadniczym zawodowym, częściej praktykujące religijnie, z jednej strony mające najtrudniejszą sytuację finan-

${ }^{11}$ G. Makowski, Mtody, bogaty, wyksztatcony, religijny - mit polskiego wolontariusza, CBOS, Warszawa 2011.

${ }^{12}$ N. Hipsz, Potencjat społecznikowski i zaangażowanie Polaków w wolontariat, CBOS, Warszawa 2012. 
sowa, z drugiej zaś - bardziej zadowolone ze swoich warunków materialnych. W grupach zawodowych to przede wszystkim kadra kierownicza i specjaliści oraz rolnicy"13. Od tego ogólnopolskiego obrazu wolontariusza Latarnicy Polski Cyfrowej nie odbiegaja zbyt mocno.

W projekcie PCRS miało działać 2600 Latarników Polski Cyfrowej. Tylu też zostało przeszkolonych i otrzymało certyfikaty ukończenia kursu. Obecnie, szacunkowo, aktywnie działa mniej niż połowa z nich. W ankiecie wzięły udział 264 osoby. Spośród badanych 67\% to kobiety, a 33\% - mężczyźni. Najmłodszy objęty badaniem Latarnik ma 17 lat, a najstarszy - 78. Średnia wieku wynosi 44 lata $(\mathrm{sd}=13)$. Większość Latarników mieszka na wsi (37,5\%) oraz w niedużych (do 100 tys. mieszkańców) miastach - 43,3\%, co wynika ze specyfiki projektu, kierowanego właśnie do osób z małych miast i wsi. Najwięcej Latarników mieszka i działa w województwie mazowieckim $(11,4 \%)$ i lubelskim (10,6\%), natomiast najmniej w lubuskim i pomorskim (2,3\%). Ponad 38\% respondentów ma wykształcenie wyższe, a 23\% - podyplomowe. Jedynie dwie osoby (co stanowi 0,4\%) mają wykształcenie podstawowe lub niepełne podstawowe. Największy odsetek wśród Latarników stanowia osoby pracujace $(72,3 \%)$ oraz emeryci i renciści $(13,6 \%)$. W'́ród uczniów i studentów, którzy stanowią 4,9\% badanej próby, większość ma zainteresowania humanistyczne $(46,2 \%)$ i społeczne $(30,8 \%)$. Dominujące branże, w których pracują bądź też pracowali Latarnicy, to kultura i sztuka $(27,7 \%)$ oraz sektor publiczny (13,6\%). W'śród respondentów dominują osoby o dochodach mieszczących się w przedziale od 1001 do 2000 zł netto miesięcznie na osobę w rodzinie $(29,9 \%)$.

Pierwszą z kwestii, która wydała się interesująca w badaniu Latarników, było ich wcześniejsze doświadczenie z wolontariatem: 80,3\% respondentów deklarowało, że angażowało się w działania wolontariackie przed przystapieniem do projektu PCRS. Dla 19,7\% projekt Polska Cyfrowa Równych Szans był pierwszym takim doświadczeniem. Ci z Latarników, którzy angażowali się wcześniej w wolontariat, najczęściej pracowali (nieodpłatnie) na rzecz organizacji pozarządowych, takich jak fundacje czy stowarzyszenia (68,8\%), a także na rzecz swojej społeczności lokalnej (67,8\%). Dalsze wyniki prezentuje tabela 1.

Latarnicy wskazywali na więcej niż jedną odpowiedź, co świadczy o dużym zróżnicowaniu ich działalności wolontariackiej. Odpowiedzi Latarników różnią się od tych deklarowanych przez Polaków w raporcie Aktywność społeczna Polaków - poziom zaangażowania i motywacje przygotowanym przez $\mathrm{CBOS}^{14}$. Polacy angażujaccy się w działalność społeczną podejmują aktywność przede wszystkim w ramach organizacji działajacych na rzecz szkolnictwa i oświaty $(22,2 \%)$, tych o charakterze religijnym $(18,5 \%)$, organizacji charytatywnych - wspierajacych osoby potrzebujace $(15,5 \%)$ lub dzieci $(14,9 \%)$, sportowych (14,8\%), a także takich, jak Ochotnicza Straż Pożarna czy Górskie Ochotnicze Pogotowie Ratunkowe (12,2\%).

13 Ibidem

14 N. Hipsz, K. Wądołowska, Aktywność społeczna Polaków - poziom zaangażowania $i$ motywacje, CBOS, Warszawa 2011. 
Latarnicy, którzy deklarowali angażowanie się w wolontariat także przed przystapieniem do PCRS, zostali zapytani o swój staż pracy wolontariusza. Latarnicy z wcześniejszym doświadczeniem wolontariackim mają średnio 14 lat (sd = 10,95) stażu w pracy na rzecz innych osób. Najdłuższy deklarowany staż to 53 lata wolontariackiej pracy, najkrótszy - rok. Z kolei 52,4\% osób, które deklarowały wcześniejsze angażowanie się w wolontariat, podejmowało działania wolontariackie kilka razy do roku. Regularnie jako wolontariusz pracowało $36,3 \%$.

\section{Tabela 1}

Wcześniejsza działalność wolontariacka Latarników Polski Cyfrowej

\begin{tabular}{|l|c|}
\hline \multicolumn{1}{|c|}{ W jakie działania wolontariackie zdarzyło się Panu/i angażować? } & Procent \\
\hline Nieodpłatna praca w organizacjach pozarządowych (fundacje, stowarzyszenia) & 68,8 \\
\hline Działania na rzecz społeczności lokalnej (osiedla, parafii, wsi, miasta) & 67,8 \\
\hline Organizacja wydarzeń społeczno-kulturalnych & 63,0 \\
\hline Wolontariat na imprezach masowych (koncerty, wydarzenia sportowe) & 52,4 \\
\hline Działalność w komitetach rodzicielskich, radach rodziców itp. & 48,6 \\
\hline Bezpośrednia pomoc lub opieka nad osobami potrzebującymi & 40,9 \\
\hline $\begin{array}{l}\text { Działalność w organizacjach charytatywnych na rzecz potrzebujących } \\
\text { (dzieci, starszych, ofiar katastrof itp.) }\end{array}$ & 32,7 \\
\hline Działalność w organizacjach ekologicznych & 11,5 \\
\hline Ochotnicza Straż Pożarna, GOPR, WOPR itp. & 10,1 \\
\hline
\end{tabular}

* Procenty nie sumują się do 100, gdyż było to pytanie wielokrotnego wyboru.

Z wcześniejszych badań (choćby tych prowadzonych przez CBOS) wiadomo, że moda na wolontariat jest najlepsza promocją tego typu działań. Latarnicy zostali więc zapytani o to, czy wśród ich najbliższych panuje moda na wolontariat. Okazuje się, że ponad 75\% Latarników ma wśród swoich najbliższych osoby, które również angażują się w działania wolontariackie.

Tabela 2

Zaangażowanie najbliższego otoczenia Latarnika w wolontariat

\begin{tabular}{|l|c|}
\hline \multicolumn{1}{|c|}{$\begin{array}{c}\text { Ile osób z Pana/i najbliższego otoczenia } \\
\text { (rodzina, znajomi, najbliżsi współpracownicy) } \\
\text { angażuje się w działania wolontariackie? }\end{array}$} & Procent \\
\hline Większość & 10,2 \\
\hline Kilka osób & 75,8 \\
\hline Nikt poza mną & 14,0 \\
\hline & Ogółem \\
\hline
\end{tabular}


Tymczasem jak wynika z ogólnopolskich badań ${ }^{15}$, jedynie $20 \%$ respondentów deklaruje, że w ich środowisku wolontariat jest popularny, a 60\% stwierdza, że wolontariat nie cieszy się w ich kręgach dużym uznaniem ${ }^{16}$. Jak wskazuja przedstawione wyżej dane, wpływ otoczenia na poziom zaangażowania w wolontariat jest bardzo duży. Prawdopodobieństwo zaangażowania się w tego typu działalność wzrasta wraz z liczbą osób z najbliższego otoczenia mających doświadczenia wolontariackie.

\section{Powody angażowania się $\mathrm{w}$ wolontariat}

W badaniach organizowanych przez CBOS, dotyczacych motywacji angażowania się w wolontariat, przeważały odpowiedzi dotyczące chęci pomocy innym (55\%) lub współczucia wobec osób potrzebujaccych (44\%) oraz wiary w siłę wspólnego działania (32\%). Rzadziej wskazywane były takie powody, jak: możliwość poznania innych osób (18\%), przekonania religijne (17\%), chęć zdobycia wiedzy i umiejętności, które moga być potrzebne w późniejszej pracy $(14 \%)^{17}$. W'́ród respondentów dominuje więc motywacja do działań wywodząca się z pobudek moralnych, rozumiana jako voluntas, czyli emocjonalna reakcja determinowana tym, co jest uznawane za dobre i słuszne. Dlatego też takie działania uznawane będą za nieracjonalne (afektywne) w Weberowskim sensie. Działania wolontaryjne będą więc rezultatem internalizacji reguł i norm społecznych, mogą mieć charakter emocjonalny i nawet odruchowy ${ }^{18}$.

Czym zatem jest wolontariat dla Latarników Polski Cyfrowej? W ankiecie pytanie dotyczące znaczenia wolontariatu dla Latarników było pytaniem otwartym, które później zostało skategoryzowane w sposób przedstawiony w tabeli 3 .

Jak wynika z powyższych statystyk, wolontariat to dla Latarników przede wszystkim bezinteresowna i bezpłatna pomoc drugiemu człowiekowi $(31,3 \%)$, praca na rzecz innych (19,7\%) oraz samorozwój i zdobywanie doświadczenia (12\%). Stowarzyszenie Klon/Jawor w jednym ze swoich badań również zapytało respondentów, jak należy rozumieć wolontariat. Pojęcie to do debaty publicznej zostało wprowadzone dopiero w latach dziewięćdziesiątych XX w., jest więc pojęciem stosunkowo młodym, do tej pory niejednoznacznie rozumianym. Wyniki są bardzo zbliżone do tych przedstawionych powyżej. Najwięcej, gdyż $66 \%$ badanych twierdzi, że wolontariat jest pomoca, a 19\% traktuje wolontariat jak pracę ${ }^{19}$.

Wyszłam z założenia, że sposób, w jaki Latarnicy definiują samo zjawisko wolontariatu, może być powiązane z ich motywacjami do zaangażowania się w projekt oraz czynnikami, które dają im satysfakcję w pracy wolontariusza.

\footnotetext{
${ }^{15}$ G. Makowski, op. cit.

16 Ibidem.

17 N. Hipsz, K. Wądołowska, op. cit.

18 M. Nowak, Teoria nieracjonalnego działania. Socjologiczne studium na temat wolontariatu i społecznego aktywizmu, UAM, Poznań 2015.

19 Źródło: civicpedia.ngo.pl [dostęp: 10.03.2016].
} 
Na podstawie odpowiedzi, jakich udzielili badani Latarnicy, możliwe okazało się wyodrębnienie kilku typów wolontariuszy biorących udział w projekcie. Poszczególne typy zostały wyodrębnione na podstawie śledzenia rozkładu częstości odpowiedzi na poszczególne pytania. Należy zaznaczyć, że przedstawione poniżej kategorie to typy idealne, miejscami wyostrzające rzeczywisty obraz. Celem budowania typologii było przygotowanie gruntu pod dalsze badanie jakościowe i wypełnienie ich treścia. $\mathrm{W}$ tej formie mają one charakter poglądowy.

\section{Tabela 3}

Znaczenie wolontariatu dla Latarników Polski Cyfrowej

\begin{tabular}{|l|c|}
\hline \multicolumn{1}{|c|}{ Czym jest dla Pana/i wolontariat? } & Procent \\
\hline Bezinteresowna i bezpłatna pomoc drugiemu człowiekowi & 31,3 \\
\hline Praca na rzecz innych (bez wynagrodzenia) & 19,7 \\
\hline Samorozwój, zdobywanie doświadczenia & 12,0 \\
\hline Dodatkowe zajęcie, sposób na wolny czas & 7,7 \\
\hline Dzielnie się wiedzą i doświadczeniem & 7,3 \\
\hline Satysfakcja i przyjemność & 6,2 \\
\hline Sposób na życie, odskocznia od codzienności & 4,6 \\
\hline Kontakt z ludźmi & 4,2 \\
\hline Świadomość bycia potrzebnym & 1,9 \\
\hline Inne & 1,9 \\
\hline Naturalny ludzki odruch & 1,5 \\
\hline Poświęcanie się & 1,5 \\
\hline & Ogółem \\
\hline
\end{tabular}

Oto jak prezentują się wyodrębnione typy wolontariuszy Latarników Polski Cyfrowej według przedstawionej przez nich definicji wolontariatu:

1. Eg o ista: Latarnik-Egoista to osoba, dla której wolontariat to przede wszystkim szansa na zaspokojenie swoich indywidualnych potrzeb, takich jak: czucie się potrzebnym, zrobienie czegoś pożytecznego, sposób na przełamanie codzienności, samorozwój, zdobywanie doświadczenia, kontakt z innymi ludźmi. Największą satysfakcję z pracy wolontariusza daje im kontakt z innymi ludźmi, czucie się potrzebnym, zdobywanie doświadczenia (kategoria, która można by zaklasyfikować do grupy: zaspokajanie własnych potrzeb). Wolontariusz-Egoista to także osoba, która oczekuje od organizatorów projektu wsparcia w postaci grantu finansowego na pokrycie ponoszonych kosztów. Zaangażował się w projekt z powodu poszukiwania kontaktów z innymi ludźmi.

2. Dobry Samarytanin: osoba, która zadeklarowała, że wolontariat to dla niej bezinteresowna pomoc innym osobom, a największą satysfakcję daje jej zadowolenie uczestników zajęć (seniorów), które prowadzi. Od organizatorów projektu potrzebuje wsparcia w postaci materiałów edukacyjnych dla 
swoich podopiecznych. Największą satysfakcję daje jej zadowolenie podopiecznych. Powodem dla, którego zaangażowała się w projekt, była chęć pomocy innym.

3. Profesjonalista - typ Latarnika, który definiuje wolontariat jako pracę bez wynagrodzenia na rzecz innych. Do swojej pracy podchodzi jak do konkretnego zadania do wykonania. Największą satysfakcję dają mu więc postępy podopiecznych, a dla odpowiedniego zrealizowania działania potrzebuje od organizatorów sprzętu komputerowego. Dla Profesjonalisty powodem udziału w PCRS była forma organizacji projektu.

W literaturze przedmiotu można znaleźć typologie wolontariuszy ułożone według motywów, jakimi kierują się oni przy angażowaniu się w dobrowolna pomoc. Daniela Becelewska wyodrębniła następujące grupy motywów podejmowania się pracy wolontariackiej: prag m a ty c z no - p r o f e s j o n a l ne (,należy coś zrobić dla innych, praca na rzecz innych wypływa z mojego zawodu, ja sobie jakoś radzę, więc muszę też pomóc innym”), hu manitarne (,ludziom potrzebującym należy pomagać, żal mi ludzi, którzy sobie nie radzą"), filozoficzno-religijne (,może ja też kiedyś będę potrzebował pomocy, pomagać należy z miłości do bliźniego, mnie też ktoś kiedyś pomógł, to teraz ja muszę spłacić ten dług") ${ }^{20}$.

Dla porównania przytaczam typologię Ewy Ger, która główną osią podziału uczyniła wartości wyznawane przez wolontariuszy. Wyróżnia ona cztery klasy wolontariuszy: wy rafinow an y ch, profesjonalistów, niedojrzałych i rzemieślników. Wyrafinowani wolontariusze nastawieni sa przede wszystkim na realizowanie własnych wartości i czerpanie jak największych korzyści ze swojej pracy (niekoniecznie materialnych) oraz zaspokojenie potrzeb uznania i prestizu. Profesjonaliści to z kolei osoby rzetelne i dbajace nie tylko o swoje potrzeby, ale także o potrzeby swoich podopiecznych. Charakteryzują się dużą elastycznością. Nie dojrzali najwyżej cenią sobie popularność. Nie zawsze sa jednak przygotowani do pełnienia roli wolontariusza. Sama chęć niesienia pomocy czyni z nich osoby warte uwagi i odpowiednie do roli wolontariusza. Ostatnia, czwarta klasa wolontariuszy, to r z e mi eślnicy. Charakterystyczne dla nich jest nieangażowanie się $\mathrm{w}$ relację $\mathrm{z}$ podopiecznym. W pracy wolontariusza ważna jest dla nich empatia, zdolności interpersonalne, doświadczenie i kompetencja.

E. Gil Clary i Mark Snyder natomiast wyodrębnili sześć funkcji osobisto-społecznych, jakie wolontariat spełnia wobec osób, które się w niego angażują: realizacja wartości (takich jak humanitaryzm), zrozumienie otaczającego świata, wzmocnienie (rozwój psychologiczny), rozwój kariery (zdobywanie doświadczenia, które może być przydatne w późniejszej ścieżce zawodowej), funkcja społeczna (wzmocnienie i zbudowanie nowych relacji interpersonalnych) i funkcja ochronna (redukowanie negatywnych emocji, takich jak poczucie winy oraz rozwiązywanie osobistych problemów) ${ }^{21}$. Owe funkcje maja

${ }^{20}$ D. Becelewska, Motywy podejmowania spontanicznej pracy wolontarnej, „Wychowanie Na Co Dzień” 2004, nr 6.

${ }^{21}$ E. G. Clary, M. Snyder, The motivations to volunteer: theoretical and practical consideration, „Current Directions in Psychological Science” 8(5), 1999, s. 156-159. 
charakter motywacyjny do podjęcia działalności wolontariackiej, a osadzone sa mocno na kilku podstawowych ludzkich potrzebach: samorealizacji, przynależności, szacunku i uznaniu. Badacze przeprowadzili badanie motywacji dorosłych Amerykanów, którzy angażują się w wolontariat. Wyniki badań wskazuja, że najczęstszymi motywatorami są: realizacja wartości, zrozumienie otaczającego świata oraz psychologiczne wzmocnienie. Zaznaczają też, że wolontariusze kierują się na ogół dwoma lub nawet trzema motywami naraz, co utrudnia jednoznaczną klasyfikację wolontariuszy jako egoistów czy też altruistów. Jedna osoba często angażuje się w wolontariat zarówno z pobudek egoistycznych, jak i altruistycznych ${ }^{22}$.

Podobna sytuacja ma miejsce w przypadku Latarników PCRS, wśród których również trudno jest jednoznacznie określić rodzaj motywacji do przystąpienia i pozostania w projekcie (altruistyczna czy też egoistyczna). Większość badanych wskazywało na kilka powodów zaangażowania się w projekt. Przy czym jedna osoba mogła wskazać jednocześnie motywy egoistyczne i altruistyczne. Wyżej przedstawione typologie mogą stanowić ważną wskazówkę dla osób rekrutujących wolontariuszy i motywujacych ich do dalszej pracy. Pozwola przygotować ofertę w taki sposób, aby każdy znalazł w niej wartości najważniejsze dla niego samego.

Poza kwestie ogólnej motywacji do angażowania się w wolontariat zapytano Latarników o konkretne powody włączenia się w projekt PCRS. Latarnicy odpowiadali, że przekonała ich idea projektu, czyli wprowadzanie osób 50+ w cyfrowy świat, a także chęć pomocy innym ludziom. Pozostałe odpowiedzi prezentuje tabela poniżej:

\section{Tabela 4}

Powody zaangażowania się w projekt PCRS

\begin{tabular}{|l|c|}
\hline \multicolumn{1}{|c|}{ Dlaczego zaangażował/a się Pan/i w projekt PCRS? } & Procent \\
\hline Spodobała mi się idea projektu (wprowadzanie osób 50+ w cyfrowy świat) & 86,7 \\
\hline Chciałem/am pomóc innym ludziom & 62,9 \\
\hline $\begin{array}{l}\text { Spodobała mi się forma organizacji projektu (szkolenia, pomoce dydaktycz- } \\
\text { ne, możliwość ubiegania się o grant, spotkania z innymi Latarnikami itp.) }\end{array}$ & 48,4 \\
\hline Chciałem/am nawiązać nowe kontakty międzyludzkie & 39,8 \\
\hline Chciałem/am pożytecznie wykorzystać swój czas & 26,6 \\
\hline \multicolumn{1}{|c|}{ Ogółem } & $264,5^{*}$ \\
\hline
\end{tabular}

* Procenty nie sumują się do 100, gdyż było to pytanie wielokrotnego wyboru.

Tym, co przyciagnęło wolontariuszy do projektu PCRS, była odpowiednio przygotowana „oferta”, która zawierała w sobie odpowiedzi na podstawowe potrzeby osób angażujących się w wolontariat: chęć pomocy innym, wykazania

22 Ibidem. 
się wiedza, pożytecznego spędzania czasu, nawiązania kontaktów z innymi, bycia częścią czegoś większego - dużej organizacji zapewniającej wsparcie merytoryczne i organizacyjne. Paul Ilsley przedstawia typologię motywów działań wolontariackich, nazywając je orientacjami. Wolontariusz może więc być zorientowany na: niesienie pomocy ludziom; na sprawę, cel i zadanie; na własne potrzeby i satysfakcję z ich zaspokojenia; na zdobywanie doświadczeń i pracę ${ }^{23}$. Latarnicy PCRS wykazują się w większości zorientowaniem na sprawę, cel i zadanie, gdyż najczęściej wskazywanym motywem zaangażowania w projekt jest właśnie idea wprowadzanie osób 50+ w cyfrowy świat i przeciwdziałanie wykluczeniu cyfrowemu (86,7\%). Następna w kolejności jest orientacja na własne potrzeby i satysfakcje ich zaspokajania (66,4\%): nawiązanie kontaktów międzyludzkich (39,8\%), pożyteczne wykorzystanie czasu $(26,6 \%)$ oraz orientacja na niesie pomocy ludziom $(62,95)$, a kolejno na zdobywanie doświadczenia i pracę - forma organizacji projektu $(48,4 \%)$.

Forma organizacji projektu zapewniała wolontariuszom merytoryczne przygotowanie do prowadzenia zajęć z osobami 50+ i rozmów z przedstawicielami władz lokalnych, pewien etos pracy Latarnika, pomoc, kiedy pojawia się trudności, poczucie wspólnoty i wspólnego celu między uczestnikami projektu. Siłą PCRS były także stojące za nim instytucje: Stowarzyszenie Miasta w Internecie, Ministerstwo Administracji i Cyfryzacji, biblioteki, które przyłączyły się do Programu Rozwoju Bibliotek. Tak zorganizowany projekt stanowił z jednej strony dodatkową zachętę dla osób, które stanowią typ człowieka heroicznie poświęcającego się dla dobra innych, a z drugiej - dawał większe szanse na powodzenie projektu, ponieważ „struktura instytucji wyznacza efektywność ekonomiczną i dobrobyt społeczeństw, dowodzi Douglas North. Jest to jedna z podstawowych tez przyjmowanych na gruncie nowej ekonomii instytucjonalnej. W ramach tego podejścia instytucje sa rozumiane jako sieci wzajemnie powiązanych norm - formalnych i nieformalnych - rządzących relacjami społecznymi” ${ }^{24}$.

\section{Wolontariacka rzeczywistość}

Badania ogólnopolskie pokazuja, że nawet w sytuacji, kiedy badani podejmowali jakieś działania na rzecz swojego środowiska lokalnego, czy też osób potrzebujących, w większości przypadków było to zaangażowanie powierzchowne i krótkotrwałe - nietrwające dłużej niż dwa tygodnie w roku. Liczba deklarowanych dni pracy społecznej w 2008 r. wskazywana najczęściej (przez $73 \%$ badanych) to 1-13 dni w roku. Jedynie $25 \%$ badanych stwierdziło, że ich zaangażowanie trwa dłużej niż 14 dni w roku ${ }^{25}$.

${ }^{23}$ P. J. Isley, Enhencing the Volunteer Experience: New Insights in Strengthening Volunteer Participation, Learning and Commitment, Jossey Bass Nonprofit \& Public Management Series, San Francisco 1990.

24 P. Matczak, A. Figiel, Sukcesy i porażki jednostek pomocniczych samorzadu terytorialnego w Poznaniu, „Ruch Prawniczy, Ekonomiczny i Socjologiczny” 69, 2006, z. 4, s. 131-148.

25 B. Wciórka, Polacy o swojej aktywności społecznej, CBOS, Warszawa 2008. 
Latarnicy przeznaczają na działalność w PCRS sporą ilość czasu wolnego - pracuja ze swoimi podopiecznymi (lub też na rzecz projektu) po kilka godzin w tygodniu (48,9\%). Decyzja o udziale w projekcie była decyzją dobrowolna w znacznej większości przypadków. Jak wskazały badania Terry'ego Beehra, Kimberly Le Gro i Kimberly Porter prowadzone wśród studentów, więcej czasu na wolontariat przeznaczały te osoby, które nie czuły się w żaden sposób przymuszane do pracy wolontariackiej ${ }^{26}$. Latarnicy sami decydowali o tym, ile czasu moga przeznaczyć na taką pracę. Wyjątek stanowią osoby, które otrzymały grant. W takiej sytuacji liczba godzin pracy i przeszkolonych osób jest regulowana umowa.

Tabela 5

Ilość czasu poświęcanego na działalność Latarnika PCRS

\begin{tabular}{|c|c|}
\hline $\begin{array}{l}\text { Ile czasu poświęca Pan/i na działalnośćc } \\
\text { jako Latarnik Polski Cyfrowej? }\end{array}$ & Procent \\
\hline Kilka godzin w tygodniu & 48,9 \\
\hline Godzinę tygodniowo & 9,8 \\
\hline Kilka godzin w miesiącu & 28,0 \\
\hline Godzinę w miesiącu & 13,3 \\
\hline Ogółem & 100,0 \\
\hline
\end{tabular}

Na podstawie deklarowanej ilości czasu poświęcanego na wolontariat powstała druga typologia wolontariuszy projektu:

1. Full-time worker: pełnoetatowy Latarnik to osoba, która miała wcześniejsze doświadczenie wolontariackie, poświęca kilka godzin w tygodniu na swoją pracę, a także angażuje się w inne działania wolontariackie równolegle z byciem Latarnikiem Polski Cyfrowej.

2. Part-time worker: pracownik tymczasowy, to Latarnik, który nie ma doświadczenia w pracy jako wolontariusz poza PCRS, poświęca na działania na rzecz projektu kilka godzin w tygodniu, nie angażuje się w inne działania wolontariackie poza PCRS.

Wśród Latarników najczęściej występującym typem jest full-time worker. Zarówno badanie Latarników, jak również badania CBOS-u dotyczące wolontariatu wskazują na to, że osoby, które już raz zaangażowały się w wolontariat, angażują się w niego po raz kolejny. Być może projekt PCRS, który przyciagnął także nowicjuszy będzie w stanie przekonać większą liczbę osób do późniejszego angażowania się w pracę wolontariacką także poza projektem.

Początkowa chęć i motywacja do włączenia się w projekt pomocy innym nie zawsze jest wystarczająca, aby w projekcie pozostać i kontynuować swoja

${ }_{26}$ T. A. Beehr et al. (2010), Required volunteers: community volunteerism among students in college classes, „Teaching of Psychology” 58(4), 2010, s. 276-280. 
pracę. Do efektywnego wykonywania swoich działań potrzebne jest poczcie satysfakcji płynące z tego, czemu wolontariusze się oddają. Dlatego też po rozpoznaniu motywacji wolontariuszy, które skłoniły ich do włączenia się w projekt, kolejną ważna kwestią okazało się to, jakie korzyści czerpią z udziału w projekcie. Zostali więc zapytani o to, co daje im największą satysfakcję w pracy Latarnika PCRS. Było to pytanie otwarte, a udzielone na nie odpowiedzi zostały pokategoryzowane na następujace grupy:

\section{Tabela 6}

Satysfakcja w pracy Latarnika Polski Cyfrowej

\begin{tabular}{|l|c|}
\hline \multicolumn{1}{|c|}{$\begin{array}{c}\text { Co daje Panu/i największą satysfakcję } \\
\text { w pracy Latarnika Polski Cyfrowej? }\end{array}$} & Procent \\
\hline Zadowolenie uczestników & 30,3 \\
\hline Postępy podopiecznych & 18,4 \\
\hline Kontakty międzyludzkie & 11,9 \\
\hline Wdzięczność podopiecznych & 10,3 \\
\hline Pomoc podopiecznym & 10,0 \\
\hline Inne & 6,5 \\
\hline Przyjemność pracy z seniorami & 2,7 \\
\hline Dzielenie się wiedzą i doświadczeniem & 2,7 \\
\hline Bycie potrzebnym & 2,3 \\
\hline Działalność Latarnika nie daje mi satysfakcji & 1,5 \\
\hline Pożyteczne wykorzystanie wolnego czasu & 1,1 \\
\hline Udział w ogólnopolskim projekcie & 1,1 \\
\hline Samorozwój & 1,1 \\
\hline & Ogółem \\
\hline
\end{tabular}

Latarnicy najczęściej odpowiadali, że to zadowolenie uczestników daje im największą satysfakcję (30,3\%), a następnie: postępy podopiecznych $(18,4 \%)$ oraz kontakty międzyludzkie (11,9\%). Należy zwrócić także uwagę na różnice w czynnikach, które dają wolontariuszom największą satysfakcję ze względu na ich wiek i płeć. Grzegorz Piekarski potwierdził swoimi badaniami prowadzonymi wśród wolontariuszy hipotezę o egzocentrycznych motywacjach kobiet związanych $\mathrm{w}$ angażowaniem się w pomoc innym oraz o endocentrycznych motywacjach mężczyzn ${ }^{27}$. Możemy założyć, że czynniki zwiększające satysfakcję z pracy również będą miały charakter egzocentryczny u kobiet, a endocentryczny u mężczyzn. Wyniki badania prowadzonego wśród Latarników

${ }_{27}$ G. Piekarski, Motywacja egzo- $i$ endocentryczna $w$ działaniach prospołecznych wobec dziatalności wolontariackiej w świetle zjawiska płci, „Edukacja” 2006, nr 4. 
wpisują się w powyższą tezę. Kobiety częściej w porównaniu z mężczyznami deklarowały, że największą satysfakcję z pracy Latarnika daje im zadowolenie podopiecznych (35,2\% kobiety, 20\% mężczyźni). Mężczyźni za to częściej wskazywali na odpowiedź na możliwość zaspokojenia własnych potrzeb jako czynniki dającego im satysfakcję z wolontariatu (30,6\% mężczyźni, 19,3\% kobiety).

Motywacje wolontariuszy również różnią się ze względu na ich wiek. W raporcie dotyczącym wolontariatu osób dojrzałych przygotowanym dla Ministerstwa Pracy i Polityki Społecznejej ${ }^{28}$ czytamy, że najważniejsze czynniki zachęcające seniorów do angażowania się w wolontariat i bycia wolontariuszem to: niesienie pomocy potrzebującym, poznanie nowych ludzi i własna satysfakcja. W przypadku Latarników kolejność „zachęt” do pozostania wolontariuszem wygląda trochę inaczej. To właśnie Latarnicy seniorzy (powyżej 55 roku życia) deklarowali najczęściej, że największą satysfakcję w pracy wolontariusza daje im zaspokojenie własnych potrzeb, takich jak kontakt z ludźmi (42,9\%). Jednak za powód zaangażowania się w PCRS podają często chęć pomocy innym ludziom.

\section{Odbiór społeczny wolontariuszy}

Wolontariusze spotykają się z różnym odbiorem ze strony bliższego i dalszego otoczenia. Wielu uważa, że bycie wolontariuszem to luksus, na który moga pozwolić sobie jedynie osoby z wysokim statusem materialnym i dużą ilością wolnego czasu. Inni nie ufają wolontariuszom, szukając podstępu w ich działalności, lub upatrują w wolontariuszach osób szukających sposobu na „załatwienie” własnych interesów. Jeszcze inni będą podziwiać wolontariuszy za odwagę i zaangażowanie w pomoc potrzebującym. Jeden $\mathrm{z}$ mitów na temat wolontariuszy został pokazany w badaniach CBOS-u Młody, bogaty, wyksztatcony, religijny - mit polskiego wolontariusza ${ }^{29}$, który odbiega od prawdziwego obrazu osób angażujących się dobrowolnie w pomoc innym.

W świetle powyższych badań interesujący wydał mi się odbiór społeczny Latarników. Jak wyniki z ich deklaracji, w większości mogli oni liczyć na wsparcie swoich najbliższych w podjętej decyzji o zostaniu Latarnikiem Polski Cyfrowej (49,2\%). Zatem 19,3\% deklaruje, że ich najbliżsi również włączyli się w projekt, niemniej $3 \% \mathrm{z}$ badanych Latarników spotkało się z brakiem wsparcia w podejmowanych działaniach.

$\mathrm{Z}$ danych przedstawionych $\mathrm{w}$ tabeli 7 wynika, że najbliższe środowisko, w którym funkcjonują Latarnicy, jest im przyjazne. Wynika to najprawdopodobniej z faktu przyzwyczajania najbliższych do bycia wolontariuszem od wielu lat, a także licznego zaangażowania osób najbliższych Latarnikom w działalność społeczną.

${ }^{28}$ F. Pazderski, P. Sobiesiak-Penszko, Wolontariat osób dojrzałych w Polsce. Ekspertyza dla Ministerstwa Pracy i Polityki Społecznej, Warszawa 2012.

${ }^{29}$ G. Makowski, op. cit. 


\section{Tabela 7}

Reakcje najbliższych na decyzję Latarników Polski Cyfrowej o zaangażowaniu się w projekt

\begin{tabular}{|c|c|}
\hline $\begin{array}{c}\text { Z jakim odbiorem ze strony Pana/i najbliższych } \\
\text { spotkała się Pana/i decyzja } \\
\text { o zaangażowanie się w projekt PCRS? }\end{array}$ & Procent \\
\hline Bardzo pozytywnym. Sami zaangażowali się w działania i pomagają mi & 19,3 \\
\hline Pozytywnym. Wspierają mnie w mojej decyzji, zachęcają do działania & 49,2 \\
\hline Neutralnym. Nie wyrażali żadnych opinii na ten temat & 28,4 \\
\hline Negatywnym. Odradzali mi ten pomysł & 3,0 \\
\hline Ogółem & 100,0 \\
\hline
\end{tabular}

Kolejną grupą osób, poza najbliższymi, z którymi kontaktowali się Latarnicy w ramach swojej pracy, byli przedstawiciele lokalnej administracji. Lokalne władze okazały się w większości przychylne wolontariuszom: 40,2\% Latarników otrzymało wsparcie w postaci miejsca do pracy z seniorami (sprzęt i salę), a aż $37,5 \%$ deklaruje otrzymanie wszelkiej niezbędnej pomocy, co dotyczyć mogło także promocji projektu oraz zachęcania seniorów do wzięcia udziału w zajęciach.

Tabela 8

Wsparcie ze strony samorządu i jego placówek

\begin{tabular}{|l|c|}
\hline $\begin{array}{c}\text { Z jakim wsparciem ze strony samorządu i jego placówek } \\
\text { (np. dom kultury, biblioteka, szkoły) spotkał/a się Pan/i w trakcie } \\
\text { swojej działalności jako Latarnik Polski Cyfrowej? }\end{array}$ & Procent \\
\hline $\begin{array}{l}\text { Otrzymałem/am wszelką niezbędną pomoc } \\
\text { Udostępniono mi salę i sprzęt komputerowy }\end{array}$ & 37,5 \\
\hline $\begin{array}{l}\text { Musiałem/am sporo się napracować, aby przekonać władze samorządowe } \\
\text { do udzielenia mi wsparcia }\end{array}$ & 40,2 \\
\hline Odmówiono mi wsparcia & 12,9 \\
\hline Ogółem & 9,5 \\
\hline
\end{tabular}

Opisana wyżej sytuacja może mieć kilka przyczyn. Od dużej świadomości władz lokalnych dotyczącej kwestii wykluczenia cyfrowego, poprzez prośby Stowarzyszenia „Miasta w Internecie” o udzielenie wsparcia Latarnikom, po dobre przygotowanie Latarników do rozmów i negocjacji z władzami lokalnymi.

Dla wielu wolontariuszy najważniejsza grupa odniesienia i miernikiem skuteczności ich pracy sa reakcje ich podopiecznych. Dlatego też Latarnicy zostali poproszeni o określenie częstotliwości, z jaką spotykają się z następującymi sytuacjami u swoich podopiecznych. 
Tabela 9

Reakcje seniorów na działalność Latarników Polski Cyfrowej

\begin{tabular}{|l|c|c|c|c|c|}
\hline \multicolumn{1}{|}{$\begin{array}{c}\text { Z jaką reakcją ze strony Pana/i } \\
\text { podopiecznych } \\
\text { (osób 50+) spotykała się Pana/i } \\
\text { działalność }\end{array}$} & $\begin{array}{c}\text { Bardzo } \\
\text { często }\end{array}$ & Często & Czasami & Rzadko & $\begin{array}{c}\text { Bardzo } \\
\text { rzadko }\end{array}$ \\
\cline { 2 - 7 } jako Latarnika Polski Cyfrowej? & \multicolumn{5}{|c|}{ Procenty } \\
\hline $\begin{array}{l}\text { Nieufność. Seniorzy „węszyli” pod- } \\
\text { stęp w mojej działalności }\end{array}$ & 2,7 & 8,3 & 14,8 & 19,3 & 54,9 \\
\hline $\begin{array}{l}\text { Zdziwienie, że „marnuję” swój czas } \\
\text { na takie działania }\end{array}$ & 7,6 & 10,2 & 22,3 & 19,3 & 40,5 \\
\hline $\begin{array}{l}\text { Uznawali moje działania za natu- } \\
\text { ralne }\end{array}$ & 12,9 & 36,0 & 25,8 & 14,8 & 10,6 \\
\hline Wdzięczność za pomoc & 55,3 & 31,1 & 8,7 & 0,4 & 4,5 \\
\hline
\end{tabular}

Zbadanie reakcji seniorów na działania Latarników było ważne, ponieważ wielu z nich czerpie siłę do dalszego działania właśnie z kontaktu ze swoimi podopiecznymi. Latarnicy wskazywali, że ich działalność najczęściej spotykała się z wdzięcznościa za pomoc ze strony podopiecznych $(55,3 \%)$, część $(12,9 \%)$ stwierdziła, że seniorzy najczęściej uznawali ich działalność za coś naturalnego. Niektórzy badani $(7,6 \%)$ najczęściej spotykali się ze zdziwieniem swoich podopiecznych faktem, że „marnują swój czas na zajmowanie się seniorami. Nieufność ze strony seniorów była wskazywana jako najczęstsza reakcja przez $2,7 \%$ badanych Latarników.

Nierzadko spotykana jest także ambiwalentna postawa wobec zjawiska wolontariatu, która może być spowodowana postrzeganiem wolontariuszy jako fanatyków, nadgorliwców, czy też - jak to ujął Coleman - „zelotów”, tak silnie zapatrzonych w swoje racje i przekonania, że nie dostrzegaja racji innych ${ }^{30}$.

\section{PODSUMOWANIE}

Jak wskazuja wyniki badań Eurobarometru, w krajach Europy Północnej i Zachodniej odsetek osób angażujących się w wolontariat jest znacznie większy niż w Polsce. Można by więc prognozować, że jest jedynie kwestią czasu uzyskanie takich wyników w Polsce. Różne badania (CBOS, Stowarzyszenie Klon/Jawor) wskazuja, że z roku na rok wolontariuszy przybywa. Wolontariat jest u nas nadal zjawiskiem wschodzącym, można już jednak zauważyć kilka jego specyficznych cech. Przede wszystkim wolontariat profesjonalizuje się, o czym świadczy coraz większy odsetek osób, które angażują się w wolontariat formalny przez pracę na rzecz organizacji pozarządowych lub biorąc udział w większych projektach (np. PCRS, wolontariat podczas Euro 2012). Kolejną

\footnotetext{
${ }^{30}$ Por. P. Matczak, A. Figiel, op. cit.
} 
kwestia, na którą należy zwrócić uwagę przy myśleniu o przyszłości wolontariatu, jest niewykorzystywany potencjał osób starszych, które to coraz chętniej w takie działania się angażuja. Badania CBOS-u wskazuja, że odsetek osób 50+ angażujących się w wolontariat wzrósł dwukrotnie z 1,4\% w 1998 do 2,6\% w 2012 r. ${ }^{31}$ Należy także pamiętać, że bez stymulowania rozwoju obywatelskiego zaangażowania i społeczeństwa obywatelskiego nie da się zwiększyć odsetka wolontariuszy, a aby to nastapiło, konieczne jest budowanie kapitału i zaufania społecznego.

Zaprezentowanie powyżej badanie stanowi jedynie wstęp do dalszej, pogłębionej analizy zjawiska wolontariatu w wykonaniu Latarników Polski Cyfrowej. Interesujące wydają się nie tylko kwestie motywacji do działania, ale przede wszystkim kapitału społecznego, jakim dysponuja Latarnicy, zmiany społecznej, jaka zaszła w ich lokalnej społeczności, a także zmian, jakie zaszły w indywidualnych biografiach Latarników.

mgr Agnieszka Szymańska-Palaczyk

Uniwersytet im. Adama Mickiewicza w Poznaniu

a.szymanska@amu.edu.pl

\section{VOLUNTEERING IN POLAND: THE DIGITAL POLAND \\ OF EQUAL OPPORTUNITIES PROJECT (PCRS)}

Sum mary

This article is a report of a survey of Lighthouse Keepers - volunteers in the project Digital Poland of Equal Opportunities (PCRS) - who are responsible for introducing people aged 50+ to the digital world. The results show the general outline of the socio-demographic characteristics of Lighthouse Keepers, their previous experience of volunteering, details of work with the project (PCRS) and the public perception of volunteers. Individual data are compared with the results of nationwide research, as well as volunteering in a European and Polish context. The results show large differences in definitions of volunteering, and hence different motivations for getting involved in this type of activity, as well as different levels of satisfaction in being a volunteer. A comparison of the Lighthouse Keepers' response with the results of nationwide surveys of volunteers points to possible similarities and differences between them; moreover the typologies presented indicate the key points of the distribution of such a heterogeneous group of volunteers as this.

${ }^{31}$ F. Pazderski, P. Sobiesiak-Penszko, op. cit. 
